\title{
Relationship between Sagittal Otolith Size and Fish Size in Engraulis encrasicolus and Sardina pilchardus (Osteichthyes: Clupeiformes) in the Southern Aegean Sea, Turkey
}

\author{
Gökçen Bilge (D)
}

Cite this article as: Bilge, G. (2018). Relationship between sagittal otolith size and fish size in Engraulis encrasicolus and Sardina pilchardus (Osteichthyes: Clupeiformes) in the southern Aegean Sea, Turkey. Aquatic Sciences and Engineering, 33(3): 72-76.

Faculty of Fisheries, Muğla Sıtkı Koçman University, Muğla, Turkey

Submitted:

25.10.2017

Accepted:

20.04.2018

Correspondence:

Gökçen Bilge

E-mail:

gbilge@mu.edu.tr

(C) Copyright 2018 by Aquatic

Sciences and Engineering

Available online at

dergipark.gov.tr/tjas

\begin{abstract}
The objective of this study was to determine the regressions between otolith size (length and height), otolith weight vs. fish length, and weight of European anchovy Engraulis encrasicolus (Linnaeus, 1758) $(n=360)$ and European pilchard Sardina pilchardus (Walbaum, 1792) ( $n=360)$, living off Güllük Bay, Turkey. Fish were caught using a purse seine between January and March 2014 in the southern Aegean Sea. No differences were found between the size and weight of the left and right otoliths. Equations were used to reconstruct the original dimensions of prey from the size of hard structures found in food samples of piscivorous predators living in or in the vicinity of the aquatic habitat. A linear regression model was used to determine the relationship between fish length and otolith size, whereas an exponential regression model was used to describe the relationships between lengths and weights of otoliths and fish for both species. All regressions yielded high coefficients of determination $\left(r^{2}\right)$ of $0.78-0.93$ for E. encrasicolus and $0.80-0.95$ for S. pilchardus. We conclude that otolith length and otolith weight are good indicators of the length and weight of the two species.
\end{abstract}

Keywords: European anchovy, European pilchard, Güllük Bay, otolith morphometry

\section{INTRODUCTION}

Otoliths are small opaque structures composed of calcium carbonate in an organic matrix and they also have vestibular and sound detection function in fishes other than lampreys, sharks, and rays (Campana, 2004). Otoliths also have a distinctive shape, which varies widely among fish families, yet can be highly species-specific (Maisey, 1987). Although they are composed of protein and calcium carbonate crystals, they are situated in the skull and therefore protected from digestion. Thus, several identification guides and keys have been published for South Africa by Smale et al. (1995), for the northeast Atlantic Ocean by Härkönen (1986), the Bering Sea by Morrow (1976), the northwest Atlantic Ocean by Campana (2004), the western Mediterranean, north and central eastern Atlantic by Tuset et al. (2008), and fossil fishes by Nolf (1985).
Otoliths can be used in diet studies of piscivorous animals, providing the whole fish is consumed or at least if the head is not discarded to such an extent that the results of the study are heavily biased (Härkönen, 1986). During feeding studies, the identification and quantification of this prey is often a difficult task: in most cases specimens are already partially or totally digested and the hard remains in the stomach, intestines, and faeces are the only diagnostic features that can be considered (Battaglia et al., 2010). Otolithsare somewhat resistant to digestion and may be used as an important tool for prey classification in several feeding studies (Pierce and Boyle, 1991; Pierce et al., 1991; Granadeiro and Silva, 2000; Battaglia et al., 2010). Furthermore, the relationship between fish length and otolith size and weight has been used with several fish species to draw conclusions on the body size and biomass of prey species (Frost and Lowry, 1980; Al-Mamry 
et al., 2010). Thus, marine biologists frequently depend on the morphology and size of conserved otoliths to examine the species and size composition of the diet of piscivore animals (Campana, 2004).

In the present study, the relationships between fish size and otolith size were studied in two marine species in the southern Aegean Sea: the European anchovy Engraulis encrasicolus (Linnaeus, 1758) and the European pilchard Sardina pilchardus (Walbaum, 1792). E. encrasicolus is a pelagic-neritic fish species forming large schools and it is a unique member of the Engraulidae family distributed in the Black Sea, the Sea of Marmara, the Aegean and the Mediterranean and estuaries of adjacent watersheds in Turkish waters (Fricke et al., 2007). The conservation status of this species was reported as vulnerable (VU) and the threats were FIT (a species that is commercially exploited as a target species) and FIB (a species that is not regularly commercially exploited, but frequently caught as bycatch in fisheries) in Turkey (Fricke et al., 2007). Sardina pilchardus is a pelagic-neritic species forming schools and it is a member of the Clupeidae family distributed in the Black Sea, the Sea of Marmara, the Aegean and the Mediterranean including adjacent estuaries and lower reaches of watersheds in Turkey (Fricke et al., 2007). the conservation status of this species was stated as near threatened in Turkey (NT) and the threats on the species were reported as FIT and as FIB by Fricke et al. (2007). Both keystone species, which have medium priority for conservation action, are sensitive to human activities (Fricke et al., 2007) and they are also economically one of the most important fish species for Turkish waters. In 2012, the total marine fish catch was 315636.5 tones in Turkey; of the catch 163981.9 tones were E. encrasicolus $(51.95 \%$ of the total catch) and 28248 tones were S. pilchardus (8.95\% of the total catch). A total of 34784.1 tones, E. encrasicolus (11141.4 tones, $32.03 \%$ of total catch) and S. pilchardus (9973.5 tones, $28.67 \%$ of total catch) have the highest ratio of catch of marine fishes for the Aegean Sea, where the present study was conducted (TUIK, 2013). Baş̧̧ınar \& Atılgan (2016), Zengin et al. (2015a, b) studied otolith morphometry and shape analysis of $E$. encrasicolus in the Black Sea and the Sea of Marmara. The aim of this study was to provide new data on the morphology and the relations between the otolith size and the fish size for the researchers studying the stomach contents and trophic interactions among marine animals in the Aegean Sea.

\section{MATERIAL AND METHOD}

The fish were collected in monthly intervals during the period of January-March 2014 off Güllük Bay (southern Aegean Sea) (Figure 1) using commercial purse seine boats. The total length (TL) of the fish was measured to the nearest $\mathrm{mm}$. Fish weight (W) was determined to the nearest $0.01 \mathrm{~g}$ on a digital balance. Sagittae (Figure 2) (total of 360 individuals, i.e., 720 otoliths per species) were removed with forceps through a cut in the cranium. Otoliths were then cleaned with $10 \% \mathrm{NaOH}$ solution and dried, and the left and right otoliths were considered separately. Each sagitta was placed with the sulcus acusticus oriented upwards and otolith length (OL) was measured in $\mathrm{mm}$ through an eye-piece micrometer under a stereo zoom microscope (Olympus SZX-16). It was defined as the longest dimension between the rostrum and postrostrum axis (nomenclature of Smale et al., 1995; Tuset et al., 2008) through the focus of the otolith (Al-Mamry et al., 2010). Otolith height $(\mathrm{OH})$ was measured in $\mathrm{mm}$ as the longest dimension between the ventral and dorsal surfaces of each sagitta. The image was taken of the internal side (medial or proximal) of the otolith as this side presents the sulcus acusticus (Tuset et al., 2008). Otolith weight (OW) was determined in mg. The paired ttest was applied to examine any dissimilarities between sagittae. When there is no significant difference $(p<0.05)$, the $H_{0}$ hypothesis $\left(b_{\text {right }}=b_{\text {left }}\right)$ was used. A single regression was used for each parameter $(\mathrm{OL}, \mathrm{OW}$, and $\mathrm{OH})$. Linear regression equations $(\mathrm{y}=\mathrm{ax}$ $+b)$ and exponential regression equations $\left(y=a x^{b}\right)$ were fitted to determine wich equations (TL-OL, TL-OH, TL-OW, W-OL, W$\mathrm{OH}, \mathrm{W}-\mathrm{OW}, \mathrm{OW}-\mathrm{OL}, \mathrm{OH}-\mathrm{OL}$ and $\mathrm{OW}-\mathrm{OH}$ ) are best describing various relations between otolith and fish size (Tarkan et al., 2007). The highest $r^{2}$ scores were used to determine which type of regression model (Linear or exponential) was used between the parameters. Moreover, some otolith shape indices were calculated: aspect ratio (OH/OL:\%) and OL/TL:\% (Tuset et al., 2008) for both species to compare with other studies on the same species.

\section{RESULT AND DISCUSSION}

The sagittal otoliths of 360 Engraulis encrasicolus and 360 Sardina pilchardus specimens were examined. Table 1 shows the descriptive statistics regarding length and weight of both species and their sagittal otoliths (with otolith width): In E. encrasico-

Table 1. Descriptive statistics of length and weight data of specimens and their otoliths obtained from the Southern Aegean Sea; Values given are the mean \pm standard deviation (SD) and range in brackets

\begin{tabular}{|c|c|c|c|c|c|c|}
\hline Species & $\mathrm{N}$ & \multicolumn{2}{|c|}{ Fish } & \multicolumn{3}{|c|}{ Otolith } \\
\hline E. encrasicolus & 360 & $\begin{array}{c}109.07 \pm 22.96 \\
{[57-150]}\end{array}$ & $\begin{array}{c}8.61 \pm 5.26 \\
{[1.21-21.21]}\end{array}$ & $\begin{array}{c}2.68 \pm 0.41 \\
{[1.7-3.4]}\end{array}$ & $\begin{array}{c}1.17 \pm 0.17 \\
{[0.8-1.5]}\end{array}$ & $\begin{array}{c}8 \pm 4 \\
{[1-21]}\end{array}$ \\
\hline
\end{tabular}


Table 2. Intercept values (a), regression slope (b) and coefficients of determination ( $\left.r^{2}\right)$ for linear $(L)$ and exponential $(E)$ relationships between otolith morphometric parameters, fish length and weight of Engraulis encrasicolus and Sardina pilchardus

\begin{tabular}{|c|c|c|c|c|c|c|}
\hline & Relationship & Regression & a & $b$ & $r^{2}$ & Significance \\
\hline \multicolumn{7}{|c|}{ Engraulis encrasicolus } \\
\hline \multirow[t]{3}{*}{ Fish Length } & TL vs. OL & $\mathrm{L}$ & 55.427 & -39.467 & 0.93 & $p<0.05$ \\
\hline & TL vs. OH & $L$ & 137.28 & -51.382 & 0.86 & $p<0.05$ \\
\hline & TL vs. OW & $E$ & 1587.4 & 0.3714 & 0.83 & $p<0.05$ \\
\hline \multirow[t]{3}{*}{ Fish Weight } & W vs. OL & $E$ & 0.1033 & 4.3187 & 0.86 & $p<0.05$ \\
\hline & W vs. OH & $E$ & 3.4932 & 4.6922 & 0.78 & $p<0.05$ \\
\hline & W vs. OW & $L$ & 12647 & -15877 & 0.85 & $p<0.05$ \\
\hline \multirow[t]{3}{*}{ Otolith } & OW vs. OL & $E$ & $2 \mathrm{E}-05$ & 3.6356 & 0.84 & $p<0.05$ \\
\hline & $\mathrm{OH}$ vs. OL & $\mathrm{L}$ & 0.3987 & 0.1002 & 0.80 & $p<0.05$ \\
\hline & $\mathrm{OW}$ vs. $\mathrm{OH}$ & $E$ & 0.0004 & 3.9387 & 0.81 & $p<0.05$ \\
\hline \multicolumn{7}{|c|}{ Sardina pilchardus } \\
\hline \multirow[t]{3}{*}{ Fish Length } & TL vs. OL & $L$ & 52.028 & 2.2924 & 0.95 & $p<0.05$ \\
\hline & TL vs. OH & $L$ & 140.2 & -44.851 & 0.84 & $p<0.05$ \\
\hline & TL vs. OW & $E$ & 880.69 & 0.2962 & 0.83 & $p<0.05$ \\
\hline \multirow[t]{3}{*}{ Fish Weight } & W vs. OL & $E$ & 1.1935 & 2.9498 & 0.82 & $p<0.05$ \\
\hline & W vs. $\mathrm{OH}$ & $E$ & 6.6862 & 4.0985 & 0.80 & $p<0.05$ \\
\hline & W vs. OW & $\mathrm{L}$ & 9880 & 1.1075 & 0.84 & $p<0.05$ \\
\hline \multirow[t]{3}{*}{ Otolith } & OW vs. OL & $E$ & $8 \mathrm{E}-05$ & 3.2972 & 0.87 & $p<0.05$ \\
\hline & $\mathrm{OH}$ vs. OL & $\mathrm{L}$ & 0.3455 & 0.3972 & 0.82 & $p<0.05$ \\
\hline & $\mathrm{OW}$ vs. $\mathrm{OH}$ & $E$ & 0.0006 & 4.5842 & 0.80 & $p<0.05$ \\
\hline
\end{tabular}

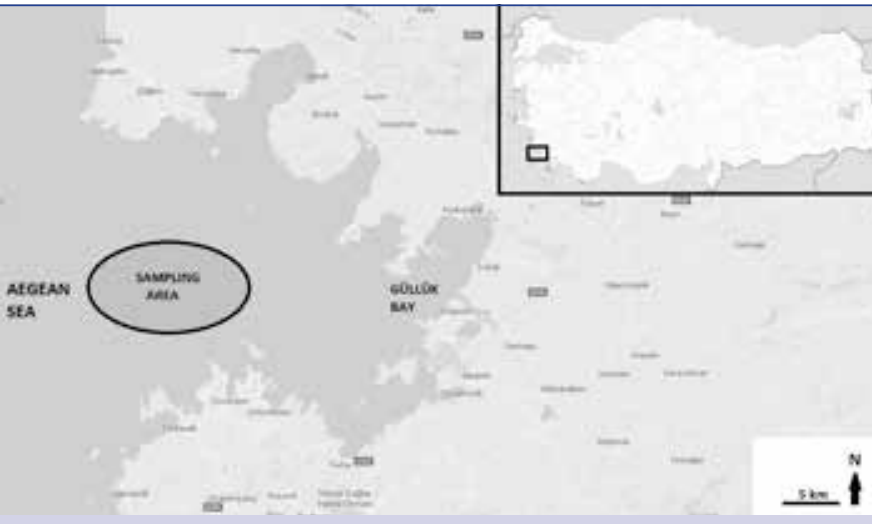

Figure 1. Map of the study area

lus, the mean total length was $109.07 \mathrm{~mm}$ (57-150 mm), and the length of otoliths ranged from 1.7 to $3.4 \mathrm{~mm}$, height from 0.8 to $1.5 \mathrm{~mm}$, and weight from 0.0001 to $0.0021 \mathrm{~g}$; in S. pilchardus, the mean total length was $126.70 \mathrm{~mm}(67-177 \mathrm{~mm})$, and the length of the otoliths 1.2-3.4 mm, their height 0.7-1.5 mm, and their weight 0.0002-0.0037 $\mathrm{g}$. Statistically no significant difference was detected (Student's t-test for paired comparisons, $p>0.05$ ) between otolith pairs. So, measurements of left sagittae were used for detecting fish and otolith size relations. The relations between fish and otolith measurements are given in Table 2. All

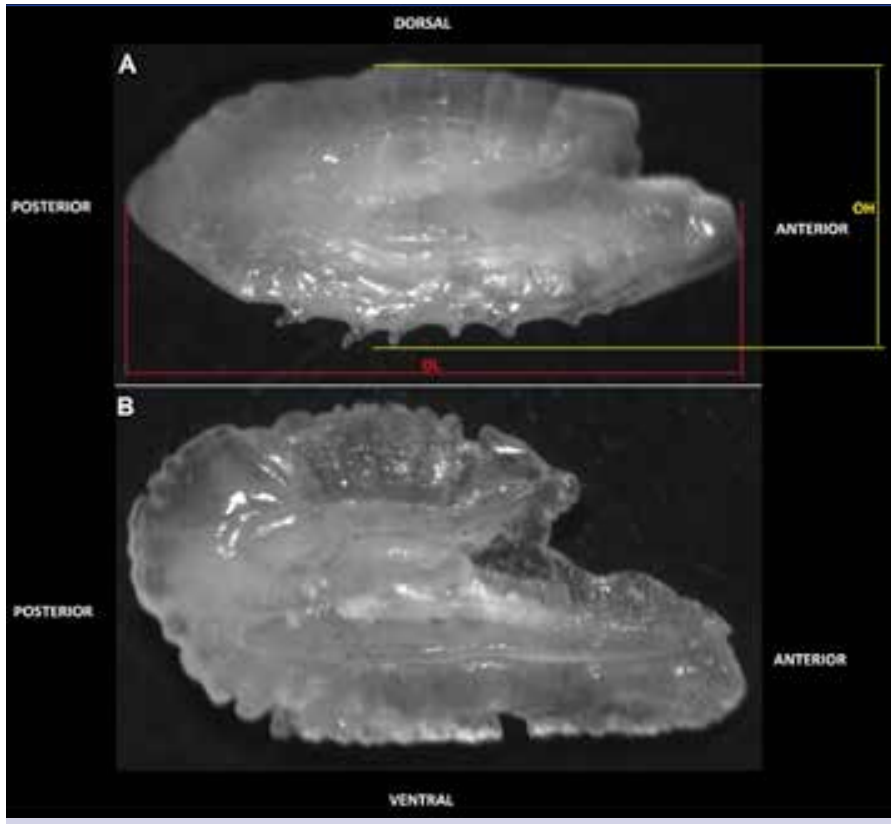

Figure 2. a, b. Left sagittal otoliths of (a) Engraulis encrasicolus ( $T L=150 \mathrm{~mm}, \mathrm{OL}=3.4 \mathrm{~mm}$ ),

(b) Sardina pilchardus ( $\mathrm{T}=150 \mathrm{~mm}, \mathrm{OL}=2.8$ $\mathrm{mm}$ ) from proximal side. $\mathrm{OL}=$ Otolith length, $\mathrm{OH}=$ Otolith height 
of them yielded a high coefficient of determination $\left(r^{2}\right)$ between 0.78 and 0.93 for $E$ encrasicolus and between 0.80 and 0.95 for $S$. pilchardus (Table 2). \% (OH/OL) and \% (OL/TL) ratios were calculated with the ranges of 39.6-48.1 and 2.2-3.1 for $E$. encrasicolus and 42.0-61.6 and 1.8-2.0 for S. pilchardus. respectively.

Both species are of great economic importance. Furthermore, they aresignificant for the trophic level in the marine environment because they are consumed by several piscivor fishes: $E$. encrasicolus are consumed by other E.encrasicolus (Valdés et al., 1987), Seriola dumerili (Matallanas et al., 1995), Trachurus mediterraneus (Santic et al., 2003), Huso huso (Berg, 1962), Alosa fallax (Assis et al., 1992), Coryphaena hippurus (Palko et al., 1982), Etmopterus spinax (Macpherson, 1979), Merluccius merluccius (Cabral and Murta, 2002), Ophichthus rufus (Casadevall et al., 1994), Scomber scombrus (Cabral and Murta, 2002), Thunnus thynnus (Sanz Brau, 1990), Galeus melastomus (Macpherson, 1979), Saurida undosquamis (Golani, 1993), Uranoscopus scaber (Sanz, 1985), Xiphias gladius (Cavaliere, 1963), Ciliata mustela (Costa, 1988), Oblada melanura (Pallaoro et al., 2004) and Elops lacerta (Hie Dare, 1980). For E. encrasicolus, our \% ratio relationships between fish (57-150 mm TL, $n=360$ ) and sagitta sizes were calculated as \% $(\mathrm{OL} / \mathrm{TL})=2.2-3.1$ and $\%(\mathrm{OH} / \mathrm{OL})=39.6-48.1$ for the Southern Aegean Sea; Tuset et al. (2008) reported these ratios as $\%(\mathrm{OL} / \mathrm{TL})=$ 2.1-2.5 and $\%(\mathrm{OH} / \mathrm{OL})=42.5-46.3$ for three specimens $(134,155$ and $177 \mathrm{~mm} \mathrm{TL}$ ) from the Western Mediterranean Sea and the Atlantic Ocean. In the present study, OL/TL ratios were found to be similar to those of Tuset et al. (2008). Başçınar and Atılgan (2016) calculated otolith length and width (height) ratios $\left(A_{R^{\prime}}\right.$ please see for the Method to Başçınar and Atılgan, 2016) of E. encrasicolus $(n=54)$ for the Black Sea coast of Ukraine, Rize and Samsun as: 1.69-2.18, 1.82-2.23 and 1.76-2.26. They calculated the equations between otolith height and length: $y=0.3224 x+0.7619\left(r^{2}=0.39\right)$ in Ukraine, $y=0.41 x+0.31\left(r^{2}=69\right)$ in Rize and $y=0.3296 x+0.5985$ $\left(r^{2}=56\right)$, with the linear regression model. According to their results, otoliths in Ukraine are different from the other two regions. Zengin et al. (2015a) were used otolith shape analyses and calculated dimensions of $E$. encrasicolus in the Black Sea( $n=137)$ and Marmara Sea $(n=126)$. According to their data, they could not find any difference between localities and between the left and right otoliths from the same locality. In addition, they offered that, otolith length was the best index for estimating fish length (please, see Zengin et al. (2015a) for the detailed data). Although Zengin et al. (2015a) noticed that the linear regression model was preferred for the examination of the relationship between fish length and otolith characteristics in most of the studies, in the present study, the exponential regression model gave higher $r^{2}$ scores than the linear regression model, especially, for the lenthweight relations. Therefore, a exponential regression model was used to explain relations between length-weight variables. Zengin et al. (2015b) also investigated some morphometric and otolith features of E.encrasicolus caught in the Black Sea and the Marmara Sea. Their results showed that there are statistical differences between the Black Sea and the Marmara Sea for otolith length and otolith weight.

Sardina pilchardus are eaten by Seriola dumerili (Matallanas et al., 1995), Seriola rivoliana (Barreiros et al., 2003), Trachurus mediterraneus (Santic et al., 2003), Trachurus trachurus (Cabral and Murta, 2002), Alosa fallax (Assis et al., 1992), Coryphaena hippurus (Massutí et al., 1998), Merluccius merluccius (Cabral and Murta, 2002), Sarda sarda (Yoshida, 1980), Scomber scombrus (Kyrtatos, 1992), Thunnus thynnus (Sanz Brau, 1990), Lepidorhombus whiffiagonis (Morte et al., 1999), Serranus cabrilla (Labropoulou and Eleftheriou, 1997), Serranus hepatus (Labropoulou and Eleftheriou, 1997), Synodus saurus (Soares et al., 2003), Chelidonichthys lucernus (Morte et al., 1997), Uranoscopus scaber (Sanz, 1985), Xiphias gladius (Cavaliere, 1963), Zeus faber (Silva, 1999), Oblada melanura (Pallaoro et al., 2004), Trisopterus luscus (Costa, 1988), and Dicentrarchus labrax (Costa, 1988). Tuset et al. (2008) reported a \% ratio relationship between the length of $S$. pilchardus $(138,175$ and $214 \mathrm{~mm} \mathrm{TL}, n=3)$ and sagitta sizes as $\mathrm{OL} / \mathrm{TL}=1.8-2.0$ and $\mathrm{OH} / \mathrm{OL}=45.5-48.7$; in the present study (67-177 $\mathrm{mm} \mathrm{TL}, n=360)$ these ratios were calculated as $\mathrm{OL} / \mathrm{TL}=1.8-2.0$ and $\mathrm{OH} / \mathrm{OL}=42.0-61.6$. In the present study, OL/TL ratios were found to be higher than those of Tuset et al. (2008), but again this may be related to the small sample size of Tuset et al. (2008).

$\mathrm{OH} / \mathrm{TL}$ ratios have larger ranges in the present study than those of Tuset et al. (2008) for both species. The largest specimen examined by Tuset et al. (2008) was larger than the specimens in this study for both species. However, in the present study, the number of specimens examined was higher than those of Tuset (2008). Tuset et al. (2008) described the sagittal otoliths of both species: having an elliptic shape and a funnel like ostium which is longer than the cauda. The cauda is tubular, straight, ending far from the posterior margin in both species. The Sulcus acusticus is heterosulcoid in E.encrasicolus but pseudo-archaesulcoid in S.pilchardus. The anterior region is peaked in both species, but the rostrum is short, broad, and pointed while the antirostrum is short, broad, peaked or poorly defined in the larger otoliths of $E$. encrasicolus $S$. pilchardus has a broad, long and pointed rostrum; and it has a larger antirostrum with otolith growth.

Many otolith atlasses, such as Härkönen (1986), Smale et al. (1995) or Tuset et al. (2008), were prepared for large geographic areas. Even though they includemany fish species, but with fewer sample sizes. This paper supplies information about the TL-OL, TL-OH, TL-OW, W-OL, W-OH, W-OW, OW-OL, OH-OL and $\mathrm{OW}-\mathrm{OH}$ relationships for $E$. encrasicolus and $S$. pilchardus in the Southern Aegean Sea. According to the data of the present study, otolith length is the best index for estimating fish length $\left(r^{2}>0.93\right)$ for both species.

\section{REFERENCES}

Al-Mamry, J., Jawad, L., Al-Busaidi, H., Al-Habsi, S., Al-Rasbi, S. (2010). Relationships between fish size and otolith size and weight in the bathypelagic species, Beryx splendens Lowe, 1834 collected from the Arabian Sea coasts of Oman. Quaderni del Museo di Storia Natturale di Livorno, 23, 79-84.

Assis, C.A., Almeida, P.R., Moreira, F., Costa, J.L., Costa, M.J. (1992). Diet of the twaite Alosa fallax (Lacépède) (Clupeidae) in the River Tagus Estuary, Portugal. Journal of Fish Biology, 41(6), 1049-1050. [CrossRef]

Barreiros, J.P., Morato, T. Santos, R.S., de Borba, A.E. (2003). Interannual changes in the diet of the Almaco jack, Seriola rivoliana (Perciformes: Carangidae) from the Azores. Cybium, 27(1), 37-40. 
Başçınar, N.S., Atılgan, E. (2016). Karadeniz'de Farklı Bölgelerde Yaşayan Hamsi (Engraulis encrasicolus, L. 1758)'nin Otolit Morfometrisi ve Şekil Analizleri: Ukrayna ve Türkiye (Rize, Samsun). Yunus Araştırma Bülteni, 4, 311-320. [CrossRef]

Battaglia, P., Malara, D., Romeo, T., Andaloro, F. (2010). Relationships between otolith size and fish size in some mesopelagic and bathypelagic species from the Mediterranean Sea (Strait of Messina, Italy). Scientia Marina, 74(3), 605-612. [CrossRef]

Berg, L.S. (1962). Freshwater fishes of the U.S.S.R. and adjacent countries. Vol: $1,4^{\text {th }}$ edition. Israel Program for Scientific Translations Ltd, Jerusalem.

Cabral, H.N., Murta, A.G. (2002). The diet of blue whiting, hake, horse mackerel and mackerel off Portugal. Journal of Applied Ichthyology, 18, 14-23. [CrossRef]

Campana, S.E. (2004). Photographic atlas of fish otoliths of the northwest Atlantic Ocean. Canadian Special Publication of Fisheries and Aquatic Sciences 133. NRC Research Press. Ottawa, Canada.

Casadevall, M., Matallanas, J., Bartolí, T. (1994). Feeding habits of Ophichthus rufus (Anguilliformes, Ophichthidae) in the western Mediterranean. Cybium, 18(4), 431-440.

Cavaliere, A. (1963). Studi sulla biologica di Xiphias gladius L. Nota II. Bollettino di Pesca Piscicoltura e Idrobiologia, 18, 143-170.

Costa, M.J. (1988). Écologie alimentaire des poissons de l'estuarie du Tage. Cybium, 12(4), 301-320.

Frost, K.J., Lowry, L.F. (1980). Feeding of ribbon seals (Phoca fasciata) in the Bering Sea in spring. Canadian Journal of Zoology, 58, 16011607. [CrossRef]

Fricke R., Bilecenoglu, M., Sarı, H.M. (2007). Annotated checklist of fish and lamprey species (Gnathostomata and Petromyzontomorphi) of Turkey, including a Red List of threatened and declining species. Stuttgarter Beiträge zur Naturkunde Serie A (Biologie). Nr. 706, 169 p.

Golani, D. (1993). The biology of the Red Sea migrant, Saurida undosquamis in the Mediterranean and comparison with the indigenous confamilial Synodus saurus (Teleostei: Synodontidae). Hydrobiologia, 271(2), 109-117. [CrossRef]

Granadeiro, J.P., Silva, M.A. (2000). The use of otoliths and vertebrae in the identification and size-estimation of fish in predator-prey studies. Cybium, 24(4), 383-393.

Härkönen, T. (1986). Guide to the otoliths of the bony fishes of the northeast Atlantic. Danbiu ApS. Biological Consultants, Hellerup, Denmark.

Hie Dare, J.P. (1980). Régime alimentaire de la phase lagunaire de Elops lacerta (C.V. 1846). Documents Scientifiques, Centre de Recherches Océanographiques, Abidjan, 11(1), 73-83.

Kyrtatos, N.A. (1982). Investigation on fishing and biology of the most important fishes of the region around the Aegean Sea. Island of Tinos. Thalassographica, 5, 1-88.

Labropoulou, M., Eleftheriou, A. (1997). The foraging ecology of two pairs of congeneric demersal fish species: importance of morphological characteristics in prey selection. Journal of Fish Biology, 50, 324-340. [CrossRef]

Macpherson, E. (1979). Relations trophiques des poisons dans la Méditerranée occidentale. Rapports Commission Internationale pour I'Exploration Scientifique de la Mer Méditerree, 25/26, 49-58.

Maisey, J.G. (1987). Notes on the structure and phylogeny of vertebrate otoliths. Copeia, 2, 495-499. [CrossRef]

Massutí, E., Deudero, S. Sánchez, P., Morales-Nin, B. (1998). Diet and feeding of dolphin (Coryphaena hippurus) in western Mediterranean waters. Bulletin of Marine Science, 63(2), 329-341.

Matallanas, J., Casadevall, M., Carrassón, M., Boix, J., Fernández, V. (1995). The food of Seriola dumerili (Pisces: Carangidae) in the Catalan Sea (western Mediterranean). Journal of the Marine Biological Association of the United Kingdom, 75(1), 257-260. [CrossRef]

Morrow, J.E. (1979). Preliminary keys to otoliths of some adult fishes of the Gulf of Alaska, Bering Sea, and Beaufort Sea. NOAA Technical Reports NMFS Circular 420. [CrossRef]
Morte, M.S., Redon M.J., Sanz-Brau, A. (1997). Trophic relationships between two gurnards Trigla lucerna and Aspitrigla obscura from the western Mediterranean. Journal of the Marine Biological Association of the United Kingdom, 77, 527-537. [CrossRef]

Morte, S., Redon, M.J., Sanz-Brau, A. (1999). Feeding ecology of two megrims Lepidorhombus boscii and Lepidorhombus whiffiagonis in the western Mediterranean (Gulf of Valencia, Spain). Journal of the Marine Biological Association of the United Kingdom, 79, 161-169. [CrossRef]

Nolf, D. (1985). Otolithi piscium, Handbook of paleoichthyology. Vol. 10. Gustav Fischer Verlag, Stutgart, New York.

Palko, B.J., Beardsley, G.L., Richards, W.J. (1982). Synopsis of the biological data on dolphin-fishes, Coryphaena hippurus Linnaeus and Coryphaena equiselis Linnaeus. FAO Fisheries Synopsis No: 130.

Pallaoro, A., Santec, M., Jardas, I. (2004). Diet composition of young-ofthe-year saddled bream, Oblada melanura(Linnaeus, 1758) from the eastern central Adriatic Sea. Journal of Applied Ichthyology, 20(4), 228-230. [CrossRef]

Pierce, G.J., Boyle, P.R. (1991). A review of methods for diet analysis in piscivorous marine mammals. Oceanography and Marine Biology: An Annual Review, 29, 409-486.

Pierce, G.J., Boyle, P.R., Diack, J.S.W. (1991). Identification of fish otoliths and bones in faeces and digestive tracks of seals. Journal of Zoology, 224(2), 320-328. [CrossRef]

Santic, M., Jardas, I., Pallaoro, A. (2003). Feeding habits of Mediterranean horse mackerel, Trachurus mediterraneus (Carangidae), in the central Adriatic Sea. Cybium, 27(4), 247-253.

Sanz, A. (1985). Contribución al estudio de la biología de Uranoscopus scaber Linnaeus, 1758 (Osteichthyes, Uranoscopidae) del Mediterráneo occidental. Investigacion Pesquera, 49, 35-46.

Sanz Brau, A. (1990). Sur la nourriture des jeunes thons rouges Thunnus thynnus (L. 1758) des côtes du Golfe de Valence. Rapports Commission Internationale pour l'Exploration Scientifique de la Mer Méditerree, 32, 274 p.

Silva, A. (1999). Feeding habits of john dory, Zeus faber, off the Portuguese continental coast. Journal of the Marine Biological Association of the United Kingdom, 79, 333-340. [CrossRef]

Smale, M.J., Watson, G., Hetch, T. (1995). Otolith atlas of southern African marine fishes. Ichthyological Monographs No. 1. J.L.B. Smith Institute of Ichthyology, Rhodes University, Grahamstown, South Africa. [CrossRef]

Soares, M.S.C., Sousa, L., Barreiros, J.P. (2003). Feeding habits of the lizardfish Synodus saurus (Linnaeus, 1758) (Actinopterygii: Synodontidae) from the Azores. Aqua, Journal of Ichthyology and Aquatic Biology, 7(1), 29-38.

Tarkan, A. N., Bilge, G., Gaygusuz, Ö., Tarkan, A.S., Gürsoy, Ç., Acıpınar, H. (2007). On the use of otoliths of a Ponto-Caspian gobiid Proterorhinus marmoratus (Pallas, 1814) (Teleostei: Gobiidae) in prey-predator studies. International Journal of Natural and Engineering Sciences, 1(3), 29-33.

TUIK, (2013). Fishery Statistics 2012. Turkish Statistical Institute, Publication Number: 4119, Ankara, 59 p.

Tuset, V.M., Lombarte, A., Assis, C.A. (2008). Otolith atlas for the western Mediterranean, north and central eastern Atlantic. Scientia Marina, 72, 7-198. [CrossRef]

Valdés, E.S., Shelton, P.A., Armstrong, M.J., Field, J.G. (1987). Cannibalism in south african anchovy: egg mortality and egg consumption rates. South African Journal of Marine Science, 5, 613-622. [CrossRef]

Yoshida, H.O., (1980). Synopsis of biological data on bonitos of the genus Sarda. NOAA Technical Reports. NMFS Circular 432. FAO Fisheries Synopsis, No. 118. 50 p. [CrossRef]

Zengin, M., Polat, N., Saygın, S., (2015a). Investigation of some morphometric and otolith features of Engraulis encrasicolus L., 1758 fished in Blacksea and Marmara Sea. Biological Diversity and Conservation, 8, $62-68$.

Zengin, M., Saygın, S., Polat, N., (2015b). Otolith shape analyses and dimensions of the Anchovy Engraulis encrasicolus L. in the Black and Marmara Seas. Sains Malaysiana, 44, 657-662. [CrossRef] 